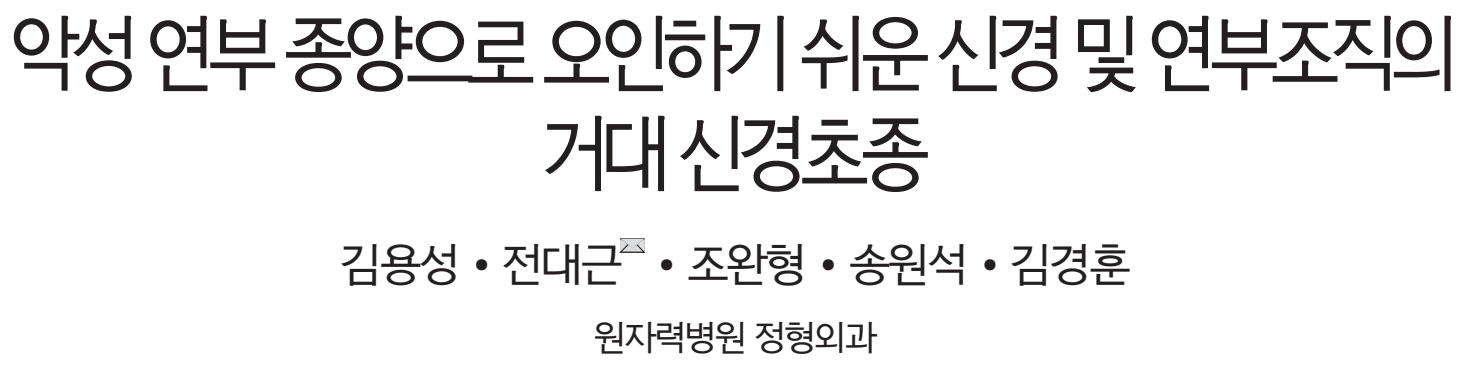

\title{
Giant Schwannoma May Mimic Soft Tissue Sarcoma
}

\author{
Yongsung Kim, M.D., Dae-Geun Jeon, M.D. ${ }^{\bowtie}$, Wan Hyeong Cho, M.D., Won Seok Song, M.D., and \\ Kyunghoon Kim, M.D. \\ Department of Orthopedic Surgery, Korea Cancer Center Hospital, Seoul, Korea
}

\begin{abstract}
Purpose: Schwannoma is a benign tumor that occurs mainly in the peripheral nerve. If the tumor is large or is in areas other than the nerves, it is likely to be mistaken for malignant soft tissue tumors. The authors reviewed 50 cases of giant schwannomas and assessed the distribution of the primary locations, clinical symptoms, radiological and pathological diagnosis, and diagnostic accuracy.

Materials and Methods: Of the 214 pathologically confirmed schwannomas, 50 cases with a maximum diameter of $5 \mathrm{~cm}$ or more were extracted. The entire cohort was classified into three subgroups (major peripheral nerve, intramuscular, bone) according to the primary location, and the anatomical locations were specified.

Results: When the entire cohort was classified according to the primary location, 14 tumors occurred in the major peripheral nerve, 31 cases in the muscle, and 5 cases in the bone. The mean size of the tumor in the entire cohort was $7.0 \mathrm{~cm}$, and the intramuscular subgroup had the largest size with $8.0 \mathrm{~cm}$. The radiological diagnosis revealed 33 out of 50 cases to be benign schwannoma $(66.0 \%), 15$ cases as low-grade malignancy $(30.0 \%)$, and the remaining two cases $(4.0 \%)$ as a suspicious tuberculosis abscess and tenosynovial giant cell tumor, respectively. On the clinical symptoms, Tinel sign was the most common in the peripheral nerve group with 78.6\% (11/14), while 93.5\% of the intramuscular group had palpation of the mass with a mean duration of 66.6 months. In the bone group, one out of five cases was reported as a low-grade malignancy. Two cases of postoperative complications were encountered; one was bleeding after tumor excision, which required hemostasis, and the other was peroneal nerve palsy after surgery.

Conclusion: When assessing the large-sized soft tissue tumors in the muscles, the possibility of a benign schwannoma should be considered if 1) there is a long period of mass palpation and 2) non-specific findings in MRI. Preoperative pathology confirmation with a biopsy can help reduce the risk of overtreatment.
\end{abstract}

Key words: peripheral nerves, muscles, bone, schwannoma, sarcoma

\section{서 론}

신경초종은 양성 신경종양으로 주로 말초신경에 발생한다. 20대
부터 50대에 걸쳐 발생하며 전체 연부조직 종양의 $5 \%$ 가량을 차 지한다. ${ }^{12)}$ 수술 전 임상적, 방사선학적 진단을 통해 감별함으로 써 해당신경에 손상을 주지 않도록 절제연을 계획하고 수술하는 것이 중요한 것으로 알려져 있다. 임상 증상 중 가장 대표적인 것 은 신경을 자극하여 발생하는 Tinel sign이고 방사선학적으로 자 기공명영상(magnetic resonance imaging, MRI)에서 특징적 인 소견은 split-fat sign, entering-exiting nerve sign, target sign 등이다..$^{-6)}$ 신경초종이 주요 말초신경의 주행을 따라 발생한 경우는 임상적 증상 및 영상학적 검사로 비교적 쉽게 감별진단이 
가능하다. 그러나 본 종양은 근육 내 신경 분지에서도 발생하며 골 내에서 생긴 것도 보고된 바 있다. ${ }^{7-10)}$ 신경초종이 주요 말초신 경 이외의 장소에 생긴 경우 MRI상 신경초종에 합당한 방사선학 적 소견이나 임상증상도 잘 보이지 않는 것으로 알려져 있다. 여 러 저자들의 연구에 의하면 근육 내 신경초종의 영상학적 특징으 로 MRI상 split-fat sign, low signal margin과 fascicular sign 이 유용함을 보고한 바 있다. 8,10-12)

해부학적으로 신경초종이 말초신경 이외의 위치에 발생할 경 우, 신경증상도 드물 뿐 아니라 방사선 검사상 특징적인 소견을 보이는 빈도가 낮아서 신경종양을 감별하기 어려운 경우가 많다. 또한 연부조직 종양의 American Joint Committee on Cancer (AJCC) 병기 진단 기준 중 하나인 크기에서 직경이 $5 \mathrm{~cm}$ 이상의
큰 종양의 경우는 악성 연부조직 종양의 가능성을 배제하기 힘들 고, 세침흡인 생검 등의 조직학적 검사를 통해서도 정확한 진단

Table 1. Distribution of Schwannomas according to the Size and the Location

\begin{tabular}{|c|c|c|c|c|}
\hline \multirow{2}{*}{ Variable } & \multicolumn{2}{|c|}{ Diameter (cm) } & \multirow{2}{*}{ Total } & \multirow{2}{*}{$p$-value } \\
\hline & $<5$ & $\geq 5$ & & \\
\hline Bone & $7(4.3)$ & $5(10.0)$ & 12 & \\
\hline Muscle & $68(41.5)$ & $31(62.0)$ & 99 & \\
\hline Nerve & $89(54.3)$ & $14(28.0)$ & 103 & \\
\hline Total & 164 & 50 & 214 & 0.008 \\
\hline
\end{tabular}

Values are presented as number only or number (\%).

Table 2. Patient Demographics and Clinicopathologic Characteristics

\begin{tabular}{|c|c|c|c|c|}
\hline Variable & Bone $(n=5)$ & Muscle $(n=31)$ & Nerve $(n=14)$ & Total $(n=50)$ \\
\hline Median age at diagnosis (yr) & 56.0 & 48.0 & 58.5 & 51.5 \\
\hline \multicolumn{5}{|l|}{ Sex } \\
\hline Male & $1(20.0)$ & $14(45.2)$ & $5(35.7)$ & $20(40.0)$ \\
\hline Female & $4(80.0)$ & $17(54.8)$ & $9(64.3)$ & $30(60.0)$ \\
\hline \multicolumn{5}{|l|}{ Symptom } \\
\hline Duration (mo) & 34.5 & 66.6 & 38.3 & 55.5 \\
\hline Palpation of mass & $2(40.0)$ & $29(93.5)$ & $7(50.0)$ & $38(76.0)$ \\
\hline Tinel sign & $1(20.0)$ & $1(3.2)$ & $11(78.6)$ & $13(26.0)$ \\
\hline \multicolumn{5}{|l|}{ Location } \\
\hline Upper extremity & $0(0)$ & $2(6.5)$ & $2(14.3)$ & $4(8.0)$ \\
\hline Lower extremity & $2(40.0)$ & $24(77.4)$ & $11(78.6)$ & $37(74.0)$ \\
\hline Axial & $3(60.0)$ & $5(16.1)$ & $1(7.1)$ & $9(18.0)$ \\
\hline Mean tumor size (cm) & $5.5(5.0-7.5)$ & $8.0(5.4-15.0)$ & $6.8(5.0-15.0)$ & $7.0(5.0-15.0)$ \\
\hline \multicolumn{5}{|l|}{ Radiologic finding } \\
\hline Target sign & $0(0)$ & $1(3.2)$ & $2(14.3)$ & $3(6.0)$ \\
\hline Split-fat sign & $0(0)$ & $10(32.3)$ & $9(64.3)$ & $19(38.0)$ \\
\hline Entering-exiting nerve sign & $0(0)$ & $2(6.5)$ & $14(100)$ & $16(32.0)$ \\
\hline Signal heterogeneity & $5(100)$ & $30(96.8)$ & $11(78.6)$ & $46(92.0)$ \\
\hline Cystic necrosis & $2(40.0)$ & $15(48.4)$ & 4 (28.6) & $21(42.0)$ \\
\hline \multicolumn{5}{|l|}{ Diagnostic procedure } \\
\hline PCNA & $3(60.0)$ & $24(77.4)$ & $2(14.3)$ & $29(58.0)$ \\
\hline Open biopsy & $2(40.0)$ & $6(19.4)$ & $1(7.1)$ & $9(18.0)$ \\
\hline None & $0(0)$ & $1(3.2)$ & $11(78.6)$ & $12(24.0)$ \\
\hline \multicolumn{5}{|l|}{ Surgical procedure } \\
\hline Wide excision & $2(40.0)$ & 18 (58.1) & $0(0)$ & $20(40.0)$ \\
\hline Marginal excision & $0(0)$ & $12(38.7)$ & $2(14.3)$ & $14(28.0)$ \\
\hline Intra-lesional & $3(60.0)$ & $1(3.2)$ & $12(85.7)$ & $16(32.0)$ \\
\hline
\end{tabular}

Values are presented as median only, number (\%), or mean (range). PCNA, percutaneous needle aspiration. 
을 얻지 못하여 절제연 설정 등 치료계획에 있어 어려움을 겪는 경우가 있다. ${ }^{13)}$ 이로 인해 광범위 절제를 시행하게 되는 경우, 필 요 이상의 절제연으로 환자의 기능적 손실을 초래할 수 있다. 주 요 신경 기원 외의 위치에 발생하는 신경초종 중에서 크기가 큰 경우, 이에 대한 임상적 증상이나 방사선상 특징, 발생빈도 및 부 위에 대해서 잘 알려져 있지 않으며 이런 종양의 수술 전 방사선 및 조직학적 검사상 진단이 어떤 양상이었는지에 대한 분석은 없 는 실정이다.

저자들은 본원에서 신경초종으로 확진된 214예의 종양의 원 발 위치별 발생빈도를 확인한 후 그중 $5 \mathrm{~cm}$ 이상의 거대 신경초 종 50예에서 1) 원발 위치의 분포 및 임상증상, 2) 술 전 방사선 및 병리학적 진단 결과 및 진단적 정확도를 알아보았다.

\section{대상 및 방법}

본원 정형외과에 2000년부터 2017년까지 수술을 시행한 후 신 경초종으로 확진된 214예를 추출하여 종양의 최대직경 $5 \mathrm{~cm}$ 를 기준으로 크기와 원발 위치에 따라 분류하였다(Table 1). 이들 중 크기가 $5 \mathrm{~cm}$ 이상인 거대 신경초종 환자 50예를 주요신경 기원, 근육 내, 골 내의 원발 위치에 따라 분류하였고 구체적인 해부학 적 위치를 분석하였다. 모든 환자에서 술 전 MRI상 감별진단을 시행하였다.

술 전 조직학적 진단방법으로 세침흡인 생검 혹은 절개 생검을 시행한 경우는 총 38예였다. MRI상 신경초종으로 판독한 12예 는 생검을 생략하였다.

병소 내 절제 16 예 중 12 예가 신경에서 생긴 것이었고 3 예는 골에 생긴 것으로 소파술을 시행하였으며 나머지 1예는 근육 내 종양이었다. 신경에서 생긴 종양의 병소 내 절제 방법은 신경손 상 가능성을 최소화하기 위하여 신경 외막을 종으로 절개한 후 종양의 실질에 도달하여 종양을 싸고 있는 막의 내측에서 수지를 이용하여 종양을 박리하였다. 종양 제거 후 신경 외막에서 발생 하는 출혈은 4-0 혹은 5-0 prolene을 이용하여 봉합하였다. 통 계학적 방법은 chi-square test 및 Fisher's exact test를 적용하 였으며 $\mathrm{p}<0.05$ 를 유의한 것으로 하였다. 통계학적 분석을 위하 여 the Statistical Package for the Social Sciences (SPSS ver. 24.0; IBM Corp., Armonk, NY, USA)를 사용하였다.

본 연구는 원자력병원 임상연구윤리위원회(Institutional Review Board)의 승인을 받아 시행되었다(IRB no. 2020-04-013).

\section{결 과}

1. 거대 신경초종의 원발 부위 분포 및 임상적 특징 214 예의 신경초종을 직경 $5 \mathrm{~cm}$ 를 기준으로 분류하였을 때, 두 군이 통계적으로 유의한 차이가 있음을 확인하였다(Table 1).
직경 $5 \mathrm{~cm}$ 이상의 거대 신경초종에서 원발 부위별로 근육 내 (intramuscular)가 31예, 주요 말초신경(nerve)이 14예, 골 내 (bone)가 5예였다(Table 2). 신체 위치상으로는 상지 5예, 하지 37예, 체간 8예였다. 주요 말초신경에 생긴 종양 중 원발신경은 좌골신경이 14 예 중 8 예로 가장 많았으며 나머지 6예 중 5예는 상하지의 신경이었으며, 1 예는 천골신경에서 발생하였다(Table 3). 근육 내 기원 31예 중 16예는 둔부 및 대퇴부였으며 이 중 6 예는 대퇴사두근에 발생하였다. 하퇴근육에 9예, 척추 주위 근 4 예, 나머지 2예는 상지근육에 발생하였다. 골에 생긴 5예는 천골 2예, 쇄골, 비골, 대퇴골이 각 1 예였다. 전체 코호트의 평균 연령 은 51.5세였다.

임상 증상으로 주요 말초신경기원의 경우는 Tinel sign이 11 예로 많았고(78.6\%), 그 외 기원의 신경초종에서는 종괴 촉지 증 상이 $76.0 \%$ 로 가장 많았다. 종괴 촉지 증상은 근육내 신경초종이 평균 66.6개월로 주요 신경(38.3개월)이나 골 내(34.5개월)에 생 긴 종양에 비해 길었다. 술 전 MRI상 최대 직경을 기준으로 측정 한 전체 코호트의 평균크기는 $7 \mathrm{~cm}(5.0-15.0 \mathrm{~cm})$ 였으며 근육 내 신경초종이 평균 $8 \mathrm{~cm}(5.4-15.0 \mathrm{~cm})$ 로 가장 컸다.

Table 3. Anatomical Location of 50 Schwannomas

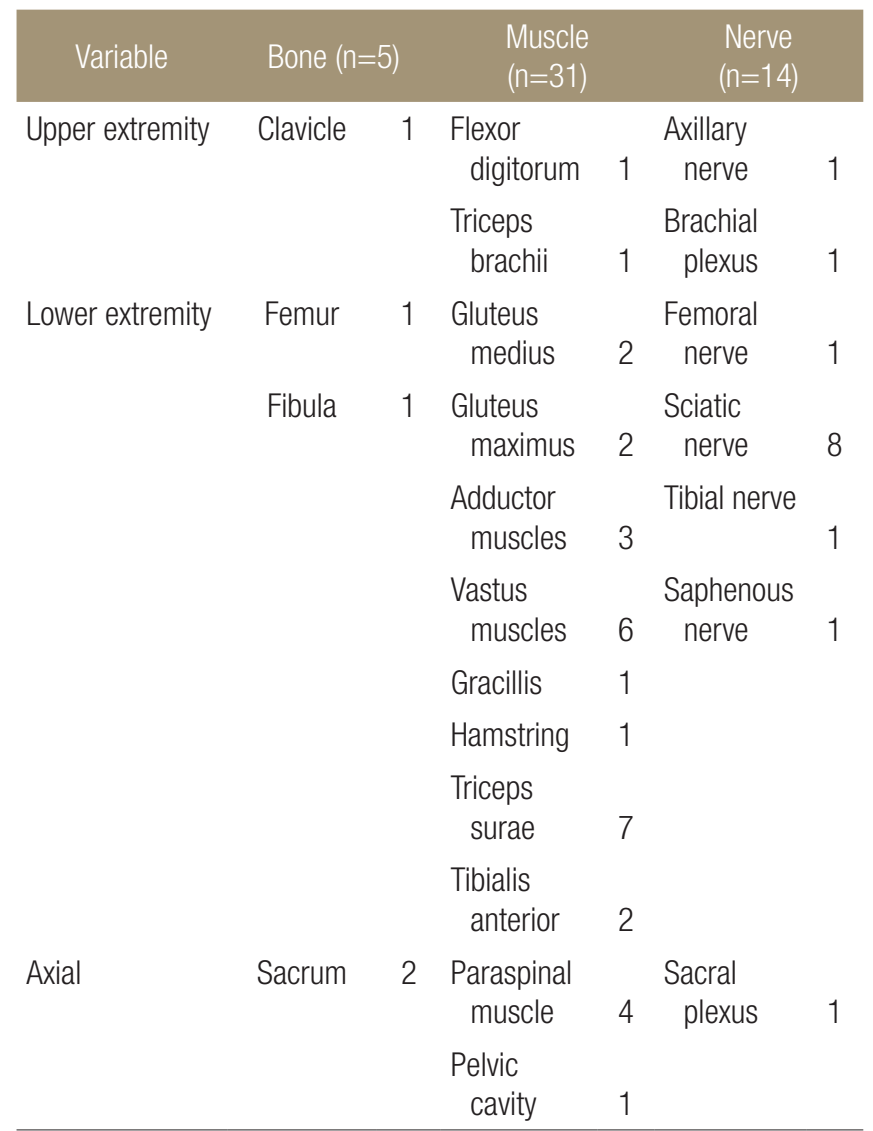


Yongsung Kim, et al.

\section{2. 영상학적 진단과 병리학적 진단의 정확도}

방사선 판독상 50예 중 33예(66.0\%)는 양성 신경초종으로 15예 (30.0\%)는 악성으로, 2예(4.0\%)는 생검이 필요하다는 소견이었 다(Table 4). 주요 말초 신경기원은 MRI에서 14예 전부 양성 신 경초종으로 판독하였으며 방사선적 진단 정확도는 $100 \%$ 였다. 근육내 신경초종은 양성 신경초종으로 판독한 것이 31 예 중 15 예(48.4\%), 악성이 14예(45.2\%), 나머지 2예(6.5\%)는 각각 결핵 농양, 건활막 거대세포종으로 보고되었다. 골 내에 생긴 것은 5예 중 4예(80.0\%)를 양성 혹은 경계성 골종양으로, 1예(20.0\%)는 악 성으로 판독하여 신경초종으로 진단한 예는 없었다.

MRI상 신경초종의 특징적인 소견인 target sign, split-fat sign, entering-exiting nerve sign 그리고 signal heterogeneity, cystic necrosis 양상을 분석하였다. 말초신경 기원 신경초 종은 entering-exiting nerve sign이 모든 예에서 관찰되었으 며 다음으로 signal heterogeneity, split-fat sign 순으로 나타 났다(Fig. 1). 근육내 신경초종에서 signal heterogeneity, cystic necrosis가 각각 30예(96.8\%), 15예(48.4\%)에서 관찰되었으 며 split-fat sign은 약 1/3인 10예(32.3\%)에서 보였으나 target sign과 entering-exiting nerve sign은 3예로 드물었다(Fig. 2). 골내 신경초종에서는 5예 모두에서 signal heterogenity가 관찰 되었다.

전체 코호트에서 조직학적 확진을 위해 생검을 시행한 경우는 38 예였다. 이 중에서 29예는 세침흡인 생검을, 7예에서 절개 생 검을 시행하였고 2 예는 세침흡인 생검과 절개 생검을 모두 시행 하였다. 나머지 12 예는 MRI상 신경초종으로 진단되어 신경손상 의 위험성을 감수하면서 세침흡인 생검을 할 필요가 없었으므로
생략하였다. 각 원발 위치에 따라서 분류하였을 때, 주요 말초신 경 기원에서는 세침흡인 생검이 2예, 절개 생검이 1예였으며 나 머지 11예는 병리학적 진단 없이 수술하였다. 근육내 신경초종에 서는 총 31예 중 30예에서 시행하였고 24예는 세침흡인 생검을, 4예는 절개 생검, 나머지 2예는 세침흡인 생검 후 추가로 절개 생 검을 하였다. 골내 신경초종은 전례에서 생검을 시행하였는데 3 예는 세침흡인 생검를 2 예는 절개 생검을 시행하였다. 세침흡인
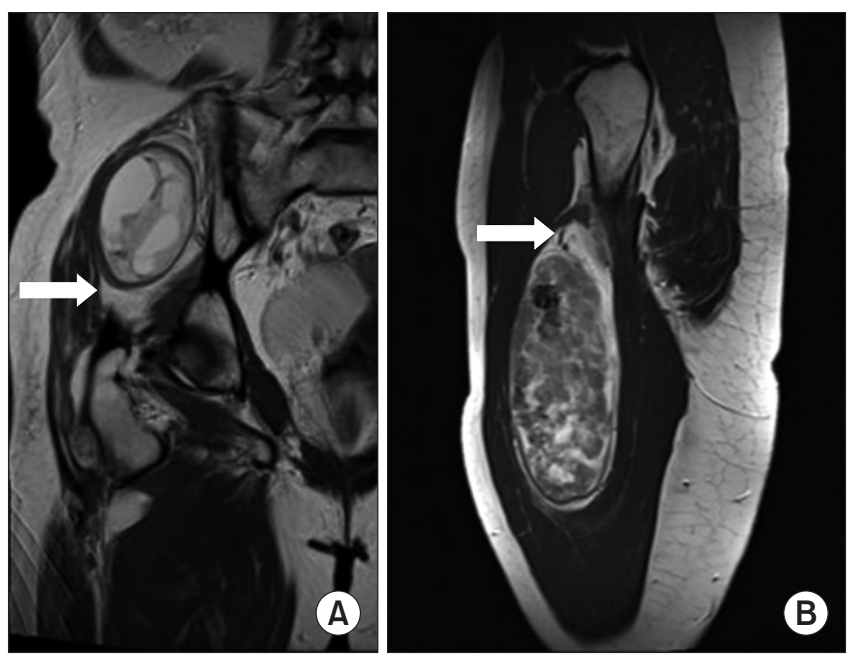

Figure 1. (A) Coronal T2-weighted magnetic resonance imaging (MRI) of an intramuscular schwannoma in the gluteus medius and (B) sagittal T2-weighted MRI with heterogneous signal intensity of an intramuscular schwannoma in the vastus intermedius. The heterogeneous signal intensity and the split-fat sign (white arrows) are visible.

Table 4. Correlation between Schwannoma and Diagnostic Procedures

\begin{tabular}{|c|c|c|c|c|}
\hline Variable & $\begin{array}{l}\text { Bone } \\
(n=5)\end{array}$ & $\begin{array}{l}\text { Muscle } \\
(n=31)\end{array}$ & $\begin{array}{l}\text { Nerve } \\
(n=14)\end{array}$ & $\begin{array}{c}\text { Total } \\
(n=50)\end{array}$ \\
\hline \multicolumn{5}{|l|}{ Radiologic report } \\
\hline Malignancy & $1(20.0)$ & $14(45.2)$ & $0(0)$ & $15(30.0)$ \\
\hline Other & $0(0)$ & $2(6.5)$ & $0(0)$ & $2(4.0)$ \\
\hline \multicolumn{5}{|l|}{ Pathology report } \\
\hline Benign neurogenic tumor & $2(40.0)$ & $2(6.6)$ & $2(14.3)$ & $6(15.8)$ \\
\hline Low grade spindle cell sarcoma & $1(20.0)$ & $4(13.3)$ & $0(10)$ & $5(13.2)$ \\
\hline Spindle cell favor benign & $0(0)$ & $7(23.3)$ & $0(0)$ & $7(18.4)$ \\
\hline
\end{tabular}

Values are presented as number (\%). 
생검상 atypical spindle cell 및 necrotic debri with atypical cells로 판독한 것은 양성 연부조직 종양으로 간주하였다. 수술 은 광범위 절제가 20 예, 변연부 절제가 14 예, 병소 내 절제가 16 예였다. 광범위 절제 20 예 중 2 예는 쇄골과 비골 근위부의 골내 신경초종이 각 1 예였으며 나머지 18 예는 전부 근육내 신경초종 이었다. 변연부 절제 14 예 중 12 예는 근육내 신경초종이었으며 2예는 좌골신경 기원 신경초종이었다. 병리학적 진단을 위해 세 침흡인 생검 혹은 절개 생검을 시행한 38예 중 저악성도 종양으 로 진단한 것은 5예(13.2\%)로 병리학적 검사의 진단 정확도는 $86.8 \%$ 였다. 주요 말초신경 기원 신경초종에서는 14 예 중 3예에 서 생검을 시행하였고 전례에서 양성 신경종양으로 진단하였다. 근육내 신경초종 31 예 중 저악성도 종양으로 진단한 경우는 4 예

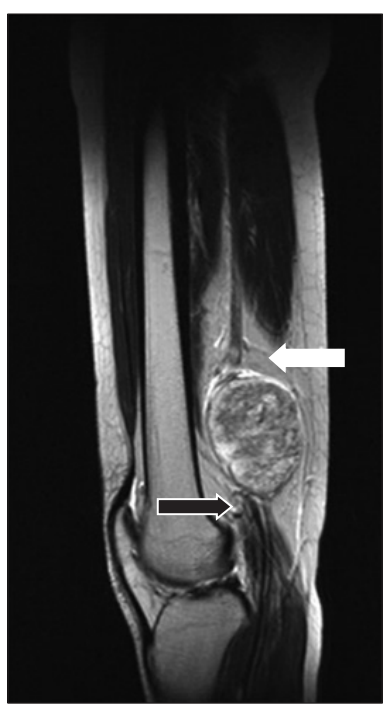

Figure 2. The entering-exiting nerve sign (white arrow) and split-fat sign (black arrow) are visible in the sagittal T2-weighted magnetic resonance imaging of a large schwannoma in sciatic nerve.
였고(12.9\%) 이 군에서의 병리학적 검사 진단 정확도는 $86.7 \%$ 였 다. 골 내에 생긴 종양은 5예 중 1예로 저악성도 종양으로 판독하 였으며 진단 정확도는 $80.0 \%$ 였다.

\section{3. 합병증}

합병증은 수술 후 합병증이 2예 보고되었다. 천골신경에 생긴 직 경 $15 \mathrm{~cm}$ 종양을 병소 내 절제한 후 신경 증상은 호전되었으나 수술 후 3 일째 혈압이 떨어지고 복부팽만이 발생하여 출혈 의심 하에 재수술하였다(Fig. 3). 종양의 신경외막에서 생긴 소동맥 출 혈을 지혈 후 증상은 소실되었다. 또한 근위 비골을 포함한 신경 초종에서 종양절제 후 경한 비골신경 마비가 발생한 경우가 있었 으며 수술 후 2주에 회복되었다.

\section{고 찰}

신경초종은 schwann cell에서 기원하는 대표적인 양성 신경종 양이다. 주로 말초신경 주행 부위에 발생하며 이 경우 임상적으 로 특징적인 Tinel sign을 보이는 경우가 많다. ${ }^{14)}$ 영상학적으로 $\mathrm{MRI}$ 에서 종괴 내부의 target sign이 관찰되거나 entering-exiting nerve sign 및 split-fat sign을 통해 말초신경 주행과의 연 속성을 확인할 수 있는 경우에 임상적으로 신경초종을 판단할 수 있다. ${ }^{15)}$ 이러한 경우 생검 절차를 생략하고 수술적 치료를 시행 하게 된다. ${ }^{16)}$ 그러나 신경 이외의 근육 내 혹은 드물게 골 내에 본 종양이 발생하며 이는 방사선 소견상 연부조직 종양과 감별 및 치료계획 설정에 어려움을 겪는 경우가 있다. Kojima 등 ${ }^{10)}$ 은 흥 추 후척추부 골 내에 발생한 신경초종 증례에서 MRI상 감별진단 으로 골모세포종을 고려하였다고 기술하였으며, Muramatsu 등8) 은 장요근 내에 발생한 $5 \mathrm{~cm}$ 의 heterogeneous cystic mass에 대해서 MRI를 통한 정확한 진단이 어려웠으며 컴퓨터 단층촬영 (computed tomography)을 이용한 생검을 통하여 조직학적 진

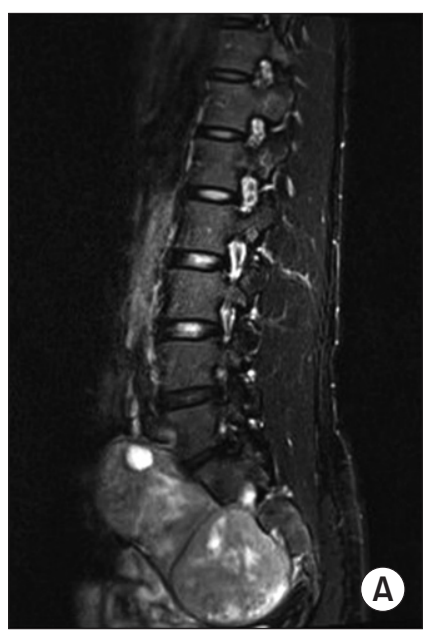

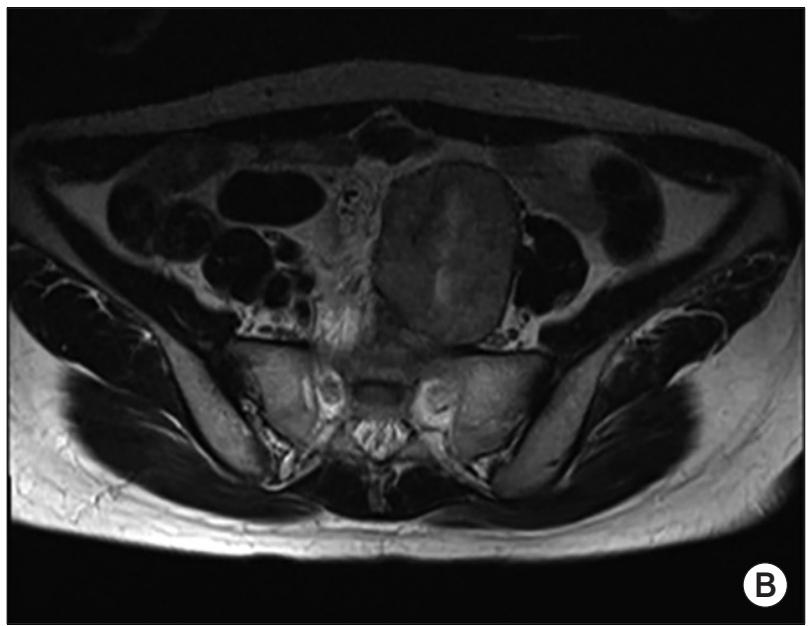

B
Figure 3. (A) The sagittal T2-weighted fat suppression and (B) the axial T2-weighted magnetic resonance imaging of a huge schwannoma originated from sacral plexus. 
단을 시행하였음을 보고하였다. ${ }^{11)}$ 이와 같이 $5 \mathrm{~cm}$ 이상의 거대 신경초종이 근육이나 골 내와 같은 주요 신경 이외의 위치에 발 생하는 경우 악성 연부조직 종양 혹은 경계성 골종양으로 오인하 여 진단 지연 혹은 과잉치료 가능성이 높다. 저자들은 $5 \mathrm{~cm}$ 이상 으로 큰 신경초종을 분석한 결과 근육 내에서 가장 많이 발생한 다는 것을 확인하였다(Table 1). 비교적 크기가 큰 신경초종이라 도 주요 말초신경 주위에 발생하면 방사선상 진단 정확도가 매우 높으나 근육 내 종양은 절반 정도에서 악성 연부육종으로 판독하 는 것을 확인할 수 있었다. 조직학적 진단을 통해서는 대부분 신 경초종을 감별할 수 있었다.

본 연구의 제한점은 첫째, 근골격계 종양을 전문으로 10 년 이 상의 경험이 있는 방사선과 의사가 $\mathrm{MRI}$ 를 판독하였으나 관찰자 간, 관찰자 내 차이가 있을 수 있다는 것이다. 둘째, 수술 전 조직 학적 진단 검사방법이 일관되지 않았다. 그러나 MRI상 신경초 종으로 진단된 경우는 신경손상의 위험성을 감수하면서 세침흡 인 생검을 할 필요가 없었으므로 생략하였다. 세침흡인 생검상 atypical spindle cell로 판독한 경우 조직의 부적절성 때문에 추 가적인 절개 생검을 한 경우가 2예 있었으나 최종 조직 소견은 세침흡입 생검과 차이가 없었다. 세침흡인 생검은 절개 생검에 비해 충분한 조직을 획득하지 못하는 점에서는 불리할 수 있으나 진단 정확도에 있어서 열등하지 않음이 잘 알려져 있으며 병리학 적 진단 검사방법의 차이가 결과에 주는 영향은 미미할 것으로 생각된다. ${ }^{17)}$

신경초종이 근육내 혹은 골내에 발생 시 진단에 어려움이 있다 고 보고 한 증례보고는 다수 있으나 $5 \mathrm{~cm}$ 가 넘는 거대 신경초종 을 원발 부위에 따라 분석한 연구는 없었다. ${ }^{11)}$ 본 연구의 결과 모 집단 214예 전체뿐만 아니라 크기 $5 \mathrm{~cm}$ 이상의 50예만을 추출 한 표본에서도 근육 내에 발생하는 경우가 유의하게 많은 것을 알 수 있었다. 근육내 신경초종은 근육량이 많은 둔부, 대퇴부에 서 많이 발견되었으며 커지더라도 종괴가 촉지되는 것 이외에는 통증과 같은 증상이 없고 Tinel sign과 같은 특징적인 임상증상 이 드물었다. 이로 인해 장기간 경과 관찰하던 중 내원하는, 지방 종과 유사한 임상경로를 보이는 것으로 생각된다. 신경초종이 두 경부, 후복부, 척추 등에 발생할 경우는 합병증을 최소화할 수술 적 절제 방법이 주요 논제인 반면, 근육 내 거대 신경초종은 연부 육종으로 오인할 가능성이 있다는 점이 중요하다. ${ }^{18-20)}$

신경 및 연부조직 종괴에 대한 기본적인 진단방법은 MRI 및 생검이다. 주요 말초신경 주위에 생긴 신경초종은 크기에 상관없 이 방사선 전문의의 MRI 판독만으로도 적절한 진단이 이루어지 는 경우가 많아 대부분 생검 절차가 필요하지 않았으며 일부 좌 골신경에 발생한 종양이 크기가 너무 크거나 신경 주위에 붙은 종괴 형상으로 보일 때 등 3예에서 생검을 시행하였으나 전부 양 성 신경종양으로 진단되었다. 따라서 주요 말초신경 기원의 거대 신경초종은 경험이 많은 방사선 전문의가 판독한 MRI 영상만으
로도 신뢰도 높은 진단이 가능하다고 판단된다. 반면 근육 내에 생긴 신경초종의 경우 절반 정도에서 악성 연부육종의 가능성이 있다고 판독하였다. 악성육종으로 오인하게 된 이유로는 1) MRI 상 악성을 시사하는 이질성 및 낭포성 괴사 등이 주된 소견이며, 2) 방사선의가 연부조직에 생긴 신경초종에 대한 경험이 거의 없 을 수 있고, 3) 제한된 임상적인 정보가 방사선의에게 주어지는 것이라고 판단된다. 이러한 이유로 31예 중 30예 대부분에서 병 리학적 진단검사를 시행하였으며 생검상으로는 약 $13 \%$ 를 제외 하고는 양성 신경종양을 진단할 수 있었다. 따라서 근육내 거대 신경초종의 경우 악성 종양을 의심하게 되는 경우가 많으나 장기 간의 종괴 촉지 소견과 비특이적인 영상학적 소견이 있을 때, 혹 은 split-fat sign이나 entering-exiting nerve sing이 관찰된다 면 양성 신경종양의 가능성도 고려하여 조직검사를 시행하면 신 뢰도 높은 조직학적 진단 결과를 얻을 수 있고, 합리적인 치료를 시행할 수 있을 것이라 생각된다. 근육내 신경초종이 MRI상 특이 한 소견이 없다고 알려져 있으나 최근 split-fat sign, low signal margin이 진단 시 유용하다고 보고되어 있으며 본 연구에서도 근육내 신경초종의 경우 $32.3 \%$ 에서 split-fat sign을 확인하였다 (Table 2). ${ }^{12)}$

한편, 골내 신경초종은 극히 드물며 발생기전에 대해서는 골 외에서 기원한 종양이 골 내로 침투하거나, 골 내의 신경관 (nerve canal)에서 기원하여 관을 확장하며 커지는 경우, 그리고 골조직 내 중심에서 발생하는 세 가지가 알려져 있다. ${ }^{21)}$ 이러한 신경초종은 MRI에서도 특징적인 소견을 확인할 수 없었고 병리 학적 진단도 주로 절개 생검을 시행하게 된다. 따라서 골 내의 거 대 종양을 진단할 경우, 통상적인 골종양의 진단법에 따르고 조 직학적 진단에 따라 치료하는 방법이 최선일 것으로 판단된다.

신경초종의 수술 후 합병증은 드물지만 대표적으로 신경의 부 분마비와 출혈이 있을 수 있다. 신경손상 가능성을 줄이기 위해 미세수술이 필요한 것으로 생각되지는 않는다. 저자들은 종양막 을 종 절개 후 종양의 실질이 나오면 과도한 박리를 하지 않고 일 부 잔존 종양이 남을 가능성이 있더라도 종양을 싸고 있는 막 내 부에서 종괴를 제거하는 것을 주 목적으로 하였다. 신경초종 수 술 후 출혈이 문제가 되는 경우는 없을 것이라 생각되나 좌골신 경이나 천추신경에 생긴 큰 종괴는 막이 두껍고 이곳에 작은 동 맥들이 분포하는 경우가 많다. 종양막을 종 절개 시 동맥 출혈이 생기면 바로 4-0 prolene으로 지혈을 하는 것이 바람직하다. 저 자들이 천추신경의 거대 신경초종 수술 후 출혈로 재수술한 경우 는 작은 동맥 출혈을 무시하고 종괴를 먼저 제거하고 나중에 지 혈을 도모하는 과정에서 출혈위치를 찾기 힘들어 재수술까지 하 게 된 경우였다. 


\section{결 론}

거대 신경초종은 근육 내에 가장 많이 분포하였고 근육 내 신경 초종은 장기간의 종괴촉지 증상이 있었다. 근육내 또는 골내 신 경초종의 경우 MRI상 진단 소견이 없어 대부분에서 조직학적 검 사를 시행하였으며 생검상 $80 \%$ 이상에서 양성 신경종양을 감별 할 수 있었다. $5 \mathrm{~cm}$ 이상의 근육 내 종양을 진단할 때 장기간의 종괴인지 소견이 있고, MRI상 비특이적인 소견일 경우에는 양상 신경종양일 가능성도 염두에 두고 조직학적 확진 후 치료를 시행 하는 것이 과잉 치료 가능성을 줄이는 데 도움이 될 것으로 생각 된다.

\section{CONFLICTS OF INTEREST}

The authors have nothing to disclose.

\section{ORCID}

Yongsung Kim, https://orcid.org/0000-0003-4203-9280

Dae-Geun Jeon, https://orcid.org/0000-0001-5722-1080

Wan Hyeong Cho, https://orcid.org/0000-0002-4768-2075

Won Seok Song, https://orcid.org/0000-0003-2852-5581

Kyunghoon Kim, https://orcid.org/0000-0002-3010-675X

\section{REFERENCES}

1. Kransdorf MJ. Benign soft-tissue tumors in a large referral population: distribution of specific diagnoses by age, sex, and location. AJR Am J Roentgenol. 1995;164:395402.

2. Murphey MD, Smith WS, Smith SE, Kransdorf MJ, Temple HT. From the archives of the AFIP. Imaging of musculoskeletal neurogenic tumors: radiologic-pathologic correlation. Radiographics. 1999;19:1253-80.

3. Cerofolini E, Landi A, DeSantis G, Maiorana A, Canossi G, Romagnoli R. MR of benign peripheral nerve sheath tumors. J Comput Assist Tomogr. 1991;15:593-7.

4. Jee WH, Oh SN, McCauley T, et al. Extraaxial neurofibromas versus neurilemmomas: discrimination with MRI. AJR Am J Roentgenol. 2004;183:629-33.

5. Kang HJ, Shin SJ, Kang ES. Schwannomas of the upper extremity. J Hand Surg Br. 2000;25:604-7.

6. Ogose A, Hotta T, Morita T, et al. Tumors of peripheral nerves: correlation of symptoms, clinical signs, imaging fea- tures, and histologic diagnosis. Skeletal Radiol. 1999;28:1838.

7. Nishio J, Ueki T, Naito M. Intramuscular schwannoma of the musculocutaneous nerve: an uncommon clinical presentation. Exp Ther Med. 2013;6:164-6.

8. Muramatsu K, Ihara K, Yoshida Y, Taguchi T. Intramuscular schwannoma arising from the psoas major muscle. Clin Neurol Neurosurg. 2008;110:532-3.

9. Haberal B, Turkbey Simsek D, Simsek EK. Intraosseous schwannoma of the calcaneus: a rare tumor of the bone. Case Rep Orthop. 2018;2018:9824025.

10. Kojima M, Seichi A, Yamamuro K, Inoue H, Kimura A, Hoshino Y. Intraosseous schwannoma originating from the posterior column of the thoracic spine. Eur Spine J. 2011;20 Suppl 2:S153-6.

11. Shimose S, Sugita T, Kubo T, et al. Major-nerve schwannomas versus intramuscular schwannomas. Acta Radiol. 2007;48:672-7.

12. Salunke AA, Chen Y, Tan JH, et al. Intramuscular schwannoma: clinical and magnetic resonance imaging features. Singapore Med J. 2015;56:555-7.

13. Amin MB, Greene FL, Edge SB, et al. The Eighth Edition AJCC Cancer Staging Manual: continuing to build a bridge from a population-based to a more "personalized" approach to cancer staging. CA Cancer J Clin. 2017;67:939.

14. Davis EN, Chung KC. The Tinel sign: a historical perspective. Plast Reconstr Surg. 2004;114:494-9.

15. Hems TE, Burge PD, Wilson DJ. The role of magnetic resonance imaging in the management of peripheral nerve tumours. J Hand Surg Br. 1997;22:57-60.

16. Koga H, Matsumoto S, Manabe J, Tanizawa T, Kawaguchi N. Definition of the target sign and its use for the diagnosis of schwannomas. Clin Orthop Relat Res. 2007;464:224-9.

17. Kilpatrick SE, Cappellari JO, Bos GD, Gold SH, Ward WG. Is fine-needle aspiration biopsy a practical alternative to open biopsy for the primary diagnosis of sarcoma? Experience with 140 patients. Am J Clin Pathol. 2001;115:59-68.

18. Maleux G, Brys P, Samson I, Sciot R, Baert AL. Giant schwannoma of the lower leg. Eur Radiol. 1997;7:1031-4.

19. Pinho R, Santana S, Farinha F, Cunha I, Barcelos A, Brenha J. Shoulder giant schwannoma- a diagnosis to be considered in painless shoulder masses. Acta Reumatol Port. 2017;42:332-3. 
Yongsung Kim, et al.

20. Rozman PA, Benjamin CG, Kondziolka D, et al. Intraosseous petrous apex schwannoma: case report and review of literature. World Neurosurg. 2019;132:182-7.
21. Gordon EJ. Solitary intraosseous neurilemmoma of the tibia: review of intraosseous neurilemmoma and neurofibroma. Clin Orthop Relat Res. 1976;117:271-82. 


\section{악성연부종양으로 오인하기쉬운신경및연부조직의 거대신경초종 \\ 김용성 • 전대근 ${ }^{凶}$ 조완형 • 송원석 • 김경훈 \\ 원자력병원 정형외과}

목적: 신경초종은 말초신경에 주로 발생하는 양성종양이나 크기가 크거나 신경 이외의 부위에서 발견될 경우 악성 연부조직 종양 으로 오인하기 쉽다. 저자들은 크기 $5 \mathrm{~cm}$ 이상의 신경초종 50예의 1) 원발 위치의 분포 및 임상증상여부, 2) 술 전 방사선 및 병리 학적 진단 결과와 진단적 정확도에 대해 알아보았다.

대상 및 방법: 신경초종으로 확진된 214예 중 자기공명영상(magnetic resonance imaging, MRI)상 종양의 최대직경이 $5 \mathrm{~cm}$ 이 상인 종양 50 예를 추출하였다. 이를 주요신경 기원, 근육 내, 골 내의 원발위치에 따라 분류하였고 구체적인 해부학적 위치를 분석 하였다.

결과: 전체 코호트에서 원발위치에 따라 분류하였을 때 주요 말초신경에 생긴 종양이 14 예, 근육 내 발생이 31 예, 골 내 발생이 5 예였다. 신경초종의 평균크기는 $7 \mathrm{~cm}$ 였으며 근육내 신경초종이 평균 $8 \mathrm{~cm}$ 로 가장 컸다. MRI를 통한 영상학적 진단에서 전체 50 예 중 33예(66.0\%)는 양성 신경종양으로, 15예(30.0\%)는 악성종양으로 판독하였으며, 나머지 2예(4.0\%)는 각각 결핵 농양, 건활 막 거대세포종으로 보고되었다. 골내 신경초종 5예 중 영상학적으로 신경초종으로 진단한 예는 없었다. 임상증상에서는 주요 신 경기원의 경우는 Tinel sign이 78.6\%로 많았고(11/14), 주요 신경 외 기원 종양에서는 종괴 촉지 증상이 93.5\%로 가장 많았으며 (29/31) 증상기간도 평균 66.6개월로 가장 길었다. 병리학적 진단을 위해 생검을 시행한 총 38 예 중 $86.8 \%$ 에서는 신경초종으로 진단하였다. 합병증은 수술 후 합병증이 총 2예였으며 종양절제 후 출혈로 재수술이 필요했던 경우와 수술 후 경한 신경마비가 발 생한 경우였다.

결론: $5 \mathrm{~cm}$ 이상의 근육 내 종양을 진단할 때 장기간의 종괴인지 소견이 있고, MRI상 비특이적인 소견일 경우에는 양상 신경종양 일 가능성도 염두에 두고 조직학적 확진 후 치료를 시행하는 것이 과잉 치료 가능성을 줄이는 데 도움이 될 것으로 생각된다.

색인단어: 말초신경, 근육, 골, 신경초종, 육종

접수일 2020년 1월 2일 수정일 2020년 3월 9일 게재확정일 2020년 4월 1일

책임저자 전대근

01812, 서울시 노원구 노원로 75, 원자력병원 정형외과

TEL 02-970-1242, FAX 02-970-2403, E-mail dgjeon@kcch.re.kr, ORCID https://orcid.org/0000-0001-5722-1080 